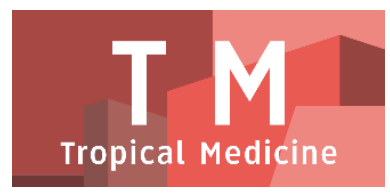

PAPER - OPEN ACCESS

\title{
Hubungan Status Depresi Dengan Kualitas Hidup Lansia Di Kota Medan
}

\author{
Author \\ DOI \\ : Rina Amelia \\ Electronic ISSN \\ : 10.32734/tm.v1i2.198 \\ Print ISSN \\ : 2623-0550 \\ : 2623-0542
}

Volume 1 Issue 2 - 2018 TALENTA Conference Series: Tropical Medicine (TM)

\section{(c) $\bigodot_{\mathrm{EY}} \ominus$}

This work is licensed under a Creative Commons Attribution-NoDerivatives 4.0 International License.

Published under licence by TALENTA Publisher, Universitas Sumatera Utara
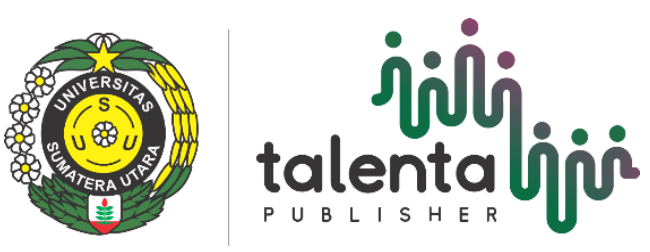


\title{
talentạli \\ Available online at https://talentaconfseries.usu.ac.id
}

\section{Hubungan Status Depresi Dengan Kualitas Hidup Lansia Di Kota Medan}

\author{
Arlinda Sari Wahyuni ${ }^{\mathrm{a}}$, Juliandi Harahap ${ }^{\mathrm{a}}$, Rina Amelia ${ }^{\mathrm{a}, *}$ \\ ${ }^{a}$ Fakultas Kedokteran, Universitas Sumatera Utara, Medan 20155, Indonesia \\ ddrrinaamelia@gmail.com
}

\begin{abstract}
Abstrak
Gangguan mental biasa terjadi di usia tua tetapi keadaan ini sering tidak terdeteksi dan tidak diobati. Gangguan mental memicu terjadinya cacat fungsional, gangguan rehabilitasi, dapat membebani sistem kesehatan dan merusak kualitas hidup pasien tua serta keluarga mereka. Tujuan penelitian ini adalah untuk menganalisisi hubungan gangguan emosional (depresi) terhadap kualitas hidup lansia di Kota Medan. Disain penelitian analitik dengan pendekataan cross sectional. Populasi penelitian adalah seluruh lansia ( $>60$ tahun) yang berada di wilayah kerja Puskesmas Tuntungan Medan. Pengambilan sampel penelitian sebanyak 100 orang (rumus proporsi) dilakukan secara consecutive sampling (kriteria inklusi dan ekslusi). Penilaian gangguan emosional menggunakan kuesioner Geriatric Depression Scale (GDS) yang terdiri dari 30 pertanyaan merupakan instrumen yang valid untuk menilai depresi yang terjadi pada lanjut usia, sedangkan penilaian kualitas hidup menggunakan kuesioner WHOQOLBREF yang terdiri dari 26 pertanyaan dengan jawaban mengunakan Skala Likert (1-5). Analisis data menggunakan uji chi squaredengan menggunakan program komputer SPSS. Hasil penelitian menunjukkan sebanyak 84 orang (84\%) lansia tidak mengalami depresi, 15 orang (15\%) lansia yang mengalami depresi ringan dan 1 orang (1\%) yang mengalami depresi berat. Kualitas hidup lansia mayoritas berada pada kategori yang cukup sebanyak 87 orang $(87 \%)$. Hasil analisis menunjukkan terdapat hubungan antara gangguan emosional (depresi) dengan kualitas hidup lansia di kota Medan ( $\mathrm{p}<0.05)$.
\end{abstract}

Kata Kunci: Depresi; Kualitas; Hidup; Lansia

\section{Pendahuluan}

Penduduk lanjut usia merupakan bagian dari anggota keluarga dan anggota masyarakat yang semakin bertambah jumlahnya sejalan dengan peningkatan usia harapan hidup. Pada tahun 1980 penduduk usia tua baru berjumlah 7,7 juta jiwa atau 5,2 persen dari seluruh jumlah penduduk. Pada tahun 1990 jumlah penduduk lanjut usia meningkat menjadi 11,3 juta orang atau 8,9 persen [1]. Jumlah ini meningkat di seluruh Indonesia menjadi 15,1 juta jiwa pada tahun 2000 atau 7,2 persen dari seluruh penduduk, dan diperkirakan pada tahun 2020 akan menjadi 29 juta orang atau 11,4 persen. Hal ini menunjukkan bahwa penduduk lanjut usia meningkat secara konsisten dari waktu ke waktu. Angka harapan hidup penduduk Indonesia berdasarkan data Biro Pusat Statistik pada tahun 1995-2000 adalah 66,0 tahun, pada tahun 2000-2005 adalah 67,8 tahun, pada tahun 2005-2010 adalah 69,1 tahun, dan pada tahun 2010-2015 adalah 70,1 tahun [2]. Di Provinsi Sumatera Utara, Badan Statistik Penduduk menunjukkan proyeksi penduduk 
dengan kelompok usia lebih dari 70 tahun pada tahun 2016 adalah 1.354 .000 dari total penduduk 71.167 .000 jiwa [3].

Secara umum kondisi fisik seseorang yang telah memasuki masa lanjut usia mengalami penurunan. Penuaan pada lanjut usia sangat dikaitkan dengan perubahan anatomi, perubahan fisiologi, terjadi kesakitan atau hal - hal yang bersifat patologi dan perubahan psikososial. Hal ini berpengaruh pada kondisi psikis, dengan berubahnya penampilan, menurunnya fungsi panca indra menyebabkan lanjut usia merasa rendah diri, mudah tersinggung dan merasa tidak berguna lagi [4]. Gangguan mental biasa terjadi di usia tua tetapi keadaan ini sering tidak terdeteksi dan tidak diobati. Gangguan mental memicu terjadinya cacat fungsional, gangguan rehabilitasi, dapat membebani sistem kesehatan dan merusak kualitas hidup pasien tua serta keluarga mereka. Pasien dengan usia tua memiliki kebutuhan besar baik untuk rehabilitasi dan untuk layanan psikososial. Selain itu, pengobatan gangguan mental dapat menentukan prognosis penyakit somatik lainnya [5] [6].

Depresi adalah gangguan psikologis yang kita ketahui sering dialami lanjut usia. Interaksi faktor biologi, fisik, psikologis, serta sosial pada lanjut usia bisa mengakibatkan depresi pada lanjut usia [7]. Depresi adalah suatu masa terganggunya fungsi dalam diri manusia yang berkaitan dengan alam perasaan yang sedih serta gejala yang menyertainya, termasuk perubahan pada pola tidur, perubahan nafsu makan, perubahan psikomotor, sulit berkonsentrasi, merasa tidak bahagia, sering merasa kelelahan, sering timbul rasa putus asa, merasa tidak berdaya, serta keinginan bunuh diri [7]. Depresi pada usia lanjut lebih sulit dideteksi salah satunya karena usia lanjut sering menutupi kesepian serta rasa sedih dengan justru lebih aktif dalam kegiatan di masyarakat [7]. Diagnosis awal dan terapi segera terhadap depresi pada pasien geriatri dapat memperbaiki kualitas hidup, status fungsional, dan mencegah kematian dini [7].

Kualitas hidup adalah persepsi individu terhadap posisi mereka dalam kehidupan pada kontek budaya dan nilai di tempat mereka hidup, serta hubungannya dengan tujuan hidup, harapan, standar, dan perhatian. Hal ini merupakan konsep yang luas yang mempengaruhi kesehatan fisik seseorang, keadaan psikologis, tingkat ketergantungan, hubungan sosial, keyakinan personal, dan hubungannya dengan keinginan di masa yang akan datang terhadap lingkungan mereka [8].Menurut World Health Organization Quality of Life (WHOQOL), kualitas hidup dibagi menjadi enam domain yaitu fisik, psikologis, tingkat kebebasan, hubungan sosial, lingkungan, spiritual, agama atau kepercayaan seseorang [9].

Tujuan penelitian ini adalah untuk menganalisisi hubungan gangguan emosional (depresi) terhadap kualitas hidup lansia di Kota Medan.

\section{Bahan dan Metode}

\subsection{Lokasi Penelitian}

Penelitian dilakukan di Puskesmas Tuntungan Kota Medan.Puskesmas Tuntungan merupakan Puskesmas yang terletak di kecamatan Medan Tuntungan yang terdiri dari 6 Kelurahan. Puskesmas Tuntungan merupakan Puskesmas yang terletak di kecamatan Medan Tuntungan yang terdiri dari 6 Kelurahan. Puskesmas Tuntungan terletak di Jl. Bunga Melati II Kelurahan Kemenangan Tani Lingkungan II Kecamatan Medan Tuntungan, dengan luas tanah sebesar $1.347 \mathrm{~m}^{2}$ dan luas bangunan sebesar $894 \mathrm{~m}^{2}$.

\subsection{Metode}

Disain penelitian analitik dengan pendekataan cross sectional. Populasi penelitian adalah seluruh lansia $(>60$ tahun) yang berada di wilayah kerja Puskesmas Tuntungan Medan. Sampel penelitian sebanyak 100 orang (rumus proporsi) yang pengambilan sampel dilakukan secara consecutive sampling (kriteria inklusi dan ekslusi). Sumber data penelitian adalah data primer.Pengambilan data menggunakan metode wawancara dengan menggunakan kuisioner. Untuk penilaian gangguan emosional/depresi menggunakan kuesioner Geriatric Depression Scale (GDS) 30. GDS 30 merupakan salah satu instrumen yang paling sering digunakan untuk mendiagnosis depresi pada usia lanjut, terdiri dari 30 pertanyaan dengan sistem penilaian skoring nilai 1 diberikan pada pernyataan bersifat positif (favorable) untuk jawaban "ya" dan nilai 0 untuk jawaban "tidak" sedangkan pernyataan bersifar negative 
(Unfavorable) jawaban "tidak" diberi nilai 1 dan jawaban "ya" diberi nilai 0 [10]. Penilaian kualitas hidup menggunakan kuesioner WHOQOL-BREF yang terdiri dari 26 item pertanyaan dengan menggunakan skala Likert 5 poin (1-5) [8]. Keikutsertaan dari lansia merupakan sukarela dan sebelum mengikuti penelitian mereka telah menandatangani inform consent. Analisis data menggunakan uji chi square dengan menggunakan program komputer SPSS.

\section{Hasil}

\subsection{Karakteristik Sampel}

Karakteristik responden penelitian meliputi jenis kelamin, usia, suku, status pernikahan, pendidikan terakhir, untuk lebih jelasnya dapat dilihat pada tabel di bawah ini.

Table. 1 Distribusi Karakteristik Lansia di Puskesmas Tuntungan

\begin{tabular}{|c|c|c|}
\hline Karakteristik Responden & Frekuensi (orang) & Persentase $(\%)$ \\
\hline \multicolumn{3}{|l|}{ Kelompok Umur } \\
\hline Elderly age (60 - 75 tahun) & 90 & 90 \\
\hline Old age ( $>75$ tahun) & 10 & 10 \\
\hline \multicolumn{3}{|l|}{ Jenis Kelamin } \\
\hline Laki-laki & 29 & 29 \\
\hline Perempuan & 71 & 71 \\
\hline \multicolumn{3}{|l|}{ Tingkat Pendidikan } \\
\hline Tidak sekolah & 5 & 5 \\
\hline Tidak tamat SD & 18 & 18 \\
\hline SD & 32 & 32 \\
\hline SLTP & 16 & 16 \\
\hline SMA & 16 & 16 \\
\hline PT & 13 & 13 \\
\hline \multicolumn{3}{|l|}{ Suku Bangsa } \\
\hline Batak & 67 & 67 \\
\hline Banjar & 1 & 1 \\
\hline Jawa & 18 & 18 \\
\hline Melayu & 9 & 9 \\
\hline Minang & 1 & 1 \\
\hline Tamil & 4 & 4 \\
\hline \multicolumn{3}{|l|}{ Status Perkawinan } \\
\hline Belum menikah & 1 & 1 \\
\hline Cerai & 2 & 2 \\
\hline Duda & 5 & 5 \\
\hline Janda & 36 & 36 \\
\hline
\end{tabular}




$\begin{array}{lcc}\text { Menikah } & 56 & 56 \\ \text { Penyakit yang menyertai } & 11 & 11 \\ \text { DM } & 30 & 30 \\ \text { Hipertensi } & 8 & 8 \\ \text { Hipertensi dan DM } & 51 & 51 \\ \text { Tidak ada } & 100 & 100 \\ \text { Jumlah } & \end{array}$

Berdasarkan Tabel 1 menunjukkan jenis kelamin mayoritas adalah perempuan sebanyak 71 orang (71\%), berdarkan umur diketahui mayoritas lansia berada pada kelompok usia 60 - 75 tahun sebanyak 90 orang (90\%), berdasarkan suku bangsa diketahui lansia mayoritas bersuku batak, yaitu 67 orang (67\%), berdasarkan status perkawinan diketahui lansia mempunyai status menikah sebanyak 56 orang (56\%), berdasarkan tingkat pendidikan mayoritas pendidikannya adalah Sekolah Dasar, yaitu 32 orang (32\%). Penyakit yang menyertai lansia paling banyak adalah hipertensi sebanyak 30 orang (31\%), sedangkan $51(51 \%)$ lansia tidak memiliki penyakit penyerta.

- Status Depresi Lansia di Puskesmas Tuntungan

Penilaian status depresi lansia menggunakan Gerriatric Depression Scale (GDS) yang hasilnya dikelompokkan menjadi tiga kategori, untuk lebih jelasnya dapat dilihat pada tabel di bawah ini:

Table. 2 Distribusi Status Depresi Lansia di Puskesmas Tuntungan

\begin{tabular}{lll}
\hline Status Depresi & Frekuensi (orang) & Persentase (\%) \\
\hline Tidak Depresi & 84 & 84 \\
Depresi Ringan & 15 & 15 \\
Depresi Sedang Berat & 1 & 1 \\
Jumlah & 100 & 100 \\
\hline
\end{tabular}

Berdasarkan Tabel 2 diketahui mayoritas lansia tidak mengalami depresi sebanyak 84 orang (84\%) dan hanya satu orang (1\%) lansia yang mengalami depresi sedang-berat.

- Kualitas Hidup Lansia di Puskesmas Tuntungan

Penilaian kualitas Hidup menggunakan penilaian kualitas hidup menurut WHOQOL untuk lebih jelasnya dapat dilihat pada tabel di bawah ini:

Table. 3 Distribusi Kualitas Hidup Lansia di Puskesmas Tuntungan

\begin{tabular}{lll}
\hline Kualitas Hidup & Frekuensi (orang) & Persentase (\%) \\
\hline Baik & 8 & 8 \\
Sedang & 87 & 87 \\
Buruk & 5 & 5 \\
Jumlah & 100 & 100 \\
\hline
\end{tabular}

Hasil Tabel 3 menunjukkan mayoritas kualitas hidup lansia berada pada kategori sedang sebanyak 87 orang (87\%). 
- Hubungan Status Depresi Kualitas Hidup Lansia di Puskesmas Tuntungan Untuk mengetahui hubungan status depresi dengan kualitas hidup lansia, dilakukan uji chi square, untul lebih jelasnya dapat dilihat pada tabel di bawah ini:

Table. 4 Hubungan Status Depresi dengan Kualitas Hidup Lansia di Puskesmas Tuntungan

\begin{tabular}{|c|c|c|c|c|c|c|c|}
\hline \multirow{2}{*}{ Status Depresi } & \multicolumn{6}{|c|}{ Kualitas Hidup } & \multirow[t]{2}{*}{$p$} \\
\hline & Baik & $\%$ & Sedang & $\%$ & Kurang & $\%$ & \\
\hline Tidak depresi & 8 & 9,52 & 74 & 88,1 & 2 & 2,39 & \multirow{2}{*}{0.0001} \\
\hline Depresi Ringan & 0 & 0 & 13 & 86,7 & 2 & 13,3 & \\
\hline Depresi Sedang Berat & 0 & 0 & 0 & 0 & 1 & 100 & \\
\hline
\end{tabular}

Hasil Tabel 4 menunjukkan dari semua lansia yang tidak mengalami depresi, mempunyai kualitas hidup yang baik yaitu sebanyak 8 orang $(9,52 \%)$, pasien yang mengalami depresi sedang, sebanyak 13 orang $(86,7 \%)$ mempunyai kualitas hidup yang sedang, dan semua pasien yang mengalami depresi sedang berat mempunyai kualitas hidup yang kurang juga sebanyak 100\%. Hasil Uji Chi square diketahui terdapat hubungan yang bermakna antara status depresi dengan kualitas hidup lansia $(\mathrm{p}<0,05)$

\section{Pembahasan}

Hasil penelitian diketahui secara umum lansia di puskesmas Tuntungan mempunyai mental emosional yang baik. Beberapa faktor resiko terjadinya depresi pada usia lanjut, yaitu jenis kelamin bahwa wanita mempunyai resiko depresi lebih dibanding laki-laki, adanya rasa kehilangan terutama orang-orang tercinta, gangguan tidur, keterbatasan fisik akibat penuaan, tingkat pendidikan yang kurang serta masalah finansial [11][12][13]. Lansia yang hidup sendiri dan tidak punya pasangan hidup (janda/duda) mempunyai resiko untuk terjadinya depresi [14]. Mental emosional yang baik pada lansia di Puskesmas Tuntungan disebabkan karena lansia mendapat dukungan yang baik dari keluarga masing-masing, hal ini dapat diketahui bahwa hampir semua lansia datang ke puskesmas yang ikut dalam penelitian ini diantar dan ditunggui oleh anggota keluarganya, dari hasil wawancara juga diketahui bahwa lansia tinggal bersama dengan keluarganya, sehingga mereka tidak merasa kesepian karena selalu berada diantara keluarganya. Hubungan yang dekat dan saling mendukung dengan keluarga akan mengurangi resiko depresi pada lansia.

Hasil penelitian menunjukkan kualitas hidup lansia mayoritas berada pada kategori sedang, hal ini dapat disebabkan karena lansia banyak merasa sangat sehat dan mampu melakukan aktivitas harian (dayly activities) secara mandiri meskipun beberapa aktivitas lain seperti naik tangga membutuhkan bantuan orang lain, sehingga mereka tetap punya semangat hidup yang baik hal ini berdampak terhadap kesehatannya. Hasil analisis menunjukkan terdapat hubungan yang bermakna antara status depresi dengan kualitas hidup lansia ( $<<0,05)$, hasil penelitian ini sejalan dengan penelitian yang dilakukan oleh Firmansyah dkk [15] Sivertsen et.al [16] bahwa semakin berat tingkat depresi lansia akan semakin buruknya kualitas hidup yang dijalani oleh lansia tersebut, semakin baik mental emosional lansia akan berdampak kualitas hidup menjadi lebih baik lagi. Depresi merupakan gangguan psikologis sering dialami lanjut usia, perubahan mental yang dialami dapat disebabkan karena perasaan kehilangan terutama pasangan hidup maupun sanak-keluarga atau teman dekat (bereavement), perasaan tidak berdaya akibat proses menua terjadi pada berbagai aspek fisik, mental, dan sosial pada lanjut usia [7] [13][17], kejadian depresi pada lansia sering tidak dideteksi dengan cepat, hal ini disebabkan oleh pada lansia kecemasan serta histeria yang merupakan suatu gejala dari depresi justru sering menutupi depresinya dan para lansia sering menutupi kesepian serta rasa sedih dengan justru lebih aktif dalam kegiatan di masyarakat sehingga gejala depresi ini tidak langsung dapat dideteksi dan mendapat penanganan yang baik 
Selain itu, penyakit kronik yang dialamai lansia yang tidak terkontrol dengan baik juga dapat berpengaruh terhadap kesehatan mental emosionalnya, hal ini desuai dengan penelitian yang dilakukan oleh Azizah [11][18] di wilayah kerja puskesmas Wonopringgo Pekalongan bahwa terdapat hubungan antara tingkat stess dengan kualitas hidup pada lansia dengan hipertensi, artinya semakin tinggi tingkat stess maka semakin menurun kualitas hidup lansia, begitu juga sebaliknya. Lansia yang terlibat pada penelitian ini 11 orang menderita diabetes, 30 orang menderita hipertensi dan 8 orang menderita DM+hipertensi, mereka merasa penyakit yang dialaminya tidak terlalu mengganggu kehidupannya dan mereka tetap rajin setiap bulan datang berobat dan kontrol ke puskesmas.

Semakin meningkat usia maka akan meningkat ketergantungan lansia kepada orang lain karena semakin berkurangnya fungsi dari tubuhnya yang berkorelasi dengan depresi yang dialaminya, hal ini sejalan dengan penelitian yang dilakukan Kathiravellu [19] bahwa kelompok elderly age mempunyai kecenderungan untuk menderita depresi 20 kali lebih tinggi, sedangkan pada kelompok umur old age didapati 11,25 kali lebih tinggi.

\section{Kesimpulan Dan Saran}

Hasil penelitian menunjukkan terdapat hubungan antara status depresi dengan kualitas hidup lansia. Screening dan konseling depresi penting dilakukan pada lansia, untuk mendeteksi kejadian depresi secara dini dan mendapatkan tatalaksana tepat, sehingga lansia tetap sehat dan bahagia di usia tuanya dan mempunyai kualitas hidup yang lebih baik. Salah satu cara untuk dapat mendeteksi dini depresi adalah mengaktifkan posyandu lansia dan menggunakan KMS Lansia sebagai indikator kesehatan lansia.

\section{Referensi}

[1] Kementrian Kesehatan Republik Indonesia. 2013. Gambaran Kesehatan Lanjut Usia di Indonesia. Buletin Jendela Data dan Informasi Kesehatan Juli. H:1-17.

[2] Badan Pusat Statistik. 2015. Statistik Penduduk Lanjut Usia. Jakarta : Badan Pusat Statistik.

[3] Badan Pusat Statistik. 2015. Proyeksi Penduduk Indonesia Indonesia Population Projection 2010-2035. Jakarta : Badan Pusat Statistik.

[4] Kaplan, Harold I, Benjamin J Sadock dan Jack A Grerr. 2005. Sinopsis Psikiatri (Ilmu Penyakit Jilid I dan II perelaku psikiatri klinis). Tangerang: Binarupa Aksara.

[5] Eva Hilger dan Pieter Fischer .2000. Mental Disorders in Old Age. Univ. Prof. Dr. Peter Fischer, Department of General Psychiatry, University Hospital of Vienna.

[6] Burt D, Zembar M, Niederehe G 1995. Depression and memory impairment: a meta-analysis of the association, its pattern, and specifity. Psychol Bull.

[7] Salim, Sudharma, Kusumaratma, Hidayat .2007. Validitas dan reliabilitas World Health Organization Quality of Life-BREF untuk mengukur kualitas hidup lanjut usia. Dibuka dari: http//Unimed.co.id

[8] WHO. 2014. WHO Quality of Life-BREF (WHOQOL-BREF). http://www.who.int/substance_abuse/research_tools/whoqolbref/en/. 15 April 2014 (13.20)

[9] WHO. 1998. Division of Mental Health and Prevention of Substance abuse. Dibuka pada website http://www.who.int/mental_health /evidence/who_qol_user-manual_manual_98.pdf

[10] The Geriatric Depression Scale (GDS) By: Sherry A. Greenberg, PhD(c), MSN, GNP-BC, Hartford Institute for Geriatric Nursing, NYU College of Nursing - Google Search [Internet]. [dikutip 3 Oktober 2017]. Tersedia pada: https://www.google.co.id/search?q=The+Geriatric+Depression+Scale+(GDS)+By\%3A+Sherry+A.+Greenberg\%2C+PhD(c)\%2C+MSN\% $2 \mathrm{C}+\mathrm{GNP}-$

$\mathrm{BC} \% 2 \mathrm{C}+$ Hartford+Institute+for + Geriatric + Nursing $\% 2 \mathrm{C}+\mathrm{NYU}+\mathrm{College}+\mathrm{of}+\mathrm{Nursing} \&$ oq $=$ The + Geriatric + Depression$+\mathrm{Scale}+(\mathrm{GDS})+\mathrm{By}$ $\% 3 \mathrm{~A}+$ Sherry+A.+Greenberg $\% 2 \mathrm{C}+\mathrm{PhD}(\mathrm{c}) \% 2 \mathrm{C}+\mathrm{MSN} \% 2 \mathrm{C}+\mathrm{GNPBC} \% 2 \mathrm{C}+\mathrm{Hartford}+$ Institute+for+Geriatric+Nursing $\% 2 \mathrm{C}+\mathrm{NYU}+\mathrm{College}$ + of + Nursing \&aqs $=$ chrome. $.69 i 57.2445$ j0j7 \& sourceid=chrome \&ie $=U T F-8$

[11] Cole MG, Dendukuri N. Risk Factors for Depression Among Elderly Community Subjects: A Systematic Review and Meta-Analysis. AJP. 1 Juni 2003;160(6):1147-56.

[12] Yan X-Y, Huang S-M, Huang C-Q, Wu W-H, Qin Y. Marital Status and Risk for Late Life Depression: A Meta-Analysis of the Published Literature. Journal of International Medical Research. Agustus 2011; 39(4): 1142-54.

[13] Demura S, Sato S. Relationships between Depression, Lifestyle and Quality of Life in the Community Dwelling Elderly: A Comparison between Gender and Age Groups. Journal of Physiological Anthropology. 2003;22(3):159-66.

[14] Dean A, Kolody B, Wood P, Matt GE. The Influence of Living Alone on Depression in Elderly Persons. Journal of Aging and Health [Internet]. 30 Juni 2016 [dikutip 3 Oktober 2017]; Tersedia pada: http://journals.sagepub.com/doi/abs/10.1177/089826439200400101

[15] Firmansyah, I., Sasmiyanto, Sofia Rhosma Dewi. 2014. Hubungan Tingkat Depresi dengan Kualitas Hidup Pada Lansia Di Kelurhan Jember Kidul Kecamatan Kaliwates Kabupaten Jember. Jember: Fakultas Ilmu Kesehatan Universitas Muhammadiyah Jember 
[16] Sivertsen, Heidi. Guro Hanevold. Knut Engedal. Geir Selbǽk. Anne-Sofie Helvik, 2015. Depression and Quality of Life in Older Person: A Review. S. Kager AG, Basel :Dementia and Geriatric Cognitive Disorder 40:311-339.

[17] Abikusno N 2013. Kelanjutusiaan Sehat Menuju Masyarakat Sehat untuk Segala Usia. Buletin Jendela Data dan Informasi Kesehatan: 2528.

[18] Azizah, Rohmatul. Rita Dwi Hartanti 2016. Hubungan antara Tingkat Stress dengan Kualitas Hidup Lansia Hipertensi di Wilayah kerja Puskesmas Wonopringgo Pekalongan.2016. The 4th University Research Coloquinum :261-278.

[19] Kathiravellu SC. Hubungan Status Depresi terhadap Kualitas Hidup Lansia di Wilayah Kerja Puskesmas Petang II Kabupaten Badung Bali Tahun 2015. ISM, 2015; 6(1). 